\title{
PENGARUH ARUS KAS OPERASI, LIKUIDITAS, LEVERAGE, DIVERSIFIKASI, DAN UKURAN PERUSAHAAN TERHADAP FINANCIAL DISTRESS (Studi empiris pada perusahaan sektor aneka industri yang terdaftar di BEI 2014-2016)
}

\author{
Febriyan \\ Ari Hadi Prasetyo* \\ Program Studi Akuntansi, Institut Bisnis dan Informatika Kwik Kian Gie, \\ Jl. Yos Sudarso Kav. 87, Jakarta 14350
}

\begin{abstract}
Recent era technology development escalate competition among companies. Most companies that unable overcome competion will not maximaze their profit, even tend to experience operating loss and the other side put the firm into financial distress. This research aims examine whether cash flow from operation, liquidity, leverage, diversification, and size are predictors that can be use to analyze companies financial distress. The sample of this research are 22 company related to various industry sector listed on IDX for year 2014-2016, the sample obtained is 66 companies. Stattistical technic analysis used are descriptive analysis, pooling test, logistic regression test, Hosmer and Lemeshow's Goodness, Wald Test, -2 Log Likelihood test, and Nagelkerke's R Square test. The data collected from secondary data, downloaded from www.idx.co.id. The research results shows that there is not enough evidence that cash flow from operation, liquidity, diversification, and size give significant effect to financial distress of company. While leverage have enough evidence gives significant effect with positive direction to the possibilty of financial distress of a company.
\end{abstract}

Keywords : Cash Flow From Operation, Liquidity, Leverage, Diversification, Size, and Financial Distress

\begin{abstract}
ABSTRAK
Pada era globalisasi ini, perkembangan teknologi yang semakin pesat membuat persaingan antar perusahaan semakin ketat. Perusahaan yang tidak mampu bersaing tentunya akan mengalami kerugian dan dapat berujung kepada kebangkrutan. Penelitian ini bertujuan untuk mengetahui apakah arus kas operasi, likuiditas, leverage, diversifikasi, dan ukuran perusahaan merupakan salah satu dari banyak informasi yang dapat digunakan untuk menganalisis penyebab financial distress suatu perusahaan. Sampel pada penelitian ini adalah 22 perusahaan manufaktur sektor aneka industri yang terdaftar di BEI dalam periode 2014-2016 sehingga total sampel yang diperoleh sebanyak 66. Teknik analisis yang digunakan adalah uji deskriptif, uji pooling, uji regresi logistik, uji Hosmer and Lemeshow's Goodness,uji Wald, uji -2 Log likelihood,dan uji Nagelkerke's $R$ Square. Data yang digunakan merupakan data sekunder yang diperoleh dari www.idx.co.id. Hasil penelitian menunjukan bahwa tidak terdapat cukup bukti bahwa arus kas operasi, likuiditas, diversifikasi dan ukuran perusahaan berpengaruh secara signifikan terhadap financial distress suatu perusahaan. Sedangkan leverage terdapat cukup bukti bahwa berpengaruh secara signifikan dengam arah positif terhadap kemungkinan financial distress suatu perusahaan
\end{abstract}

Kata Kunci : Arus Kas Operasi, Likuiditas, Leverage, diversifikasi, ukuran perusahaan, dan Financial Distress

\footnotetext{
*Alamat kini:Institut Bisnis dan Informatika Kwik Kian Gie,Jl. Yos Sudarso Kav 87,Sunter,Jakarta 14350

Penulis untuk Korespondensi: (021) 65307062 Ext. 708. Email: arihadi.prasetyo@kwikkiangie.ac.id
} 


\section{Pendahuluan}

Perkembangan di dunia yang sangat pesat membuat persaingan-persaingan dalam suatu bisnis semakin kompetitif. Persaingan suatu perusahaan sekarang ini tidaklah hanya dalam negaranya saja, melainkan juga dengan perusahaan-perusahaan yang ada di luar negaranya. Teknologi yang semakin maju membuat komunikasi setiap perusahaan antar negara semakin mudah. Hal ini akhirnya mulai menghilangkan batasan-batasan lokal suatu perusahaan dalam menjalankan bisnisnya dan mampu melakukan perdagangan bebas dimana saja. Apabila perusahaan tidak mampu bersaing maka perusahaan tersebut akan mengalami kerugian , sehingga pada akhirnya mengakibatkan perusahaan mengalami financial distress. (Srikalimah , 2017)

Kondisi perekonomian suatu negara pastinya juga mempengaruhi kondisi dan perkembangan suatu perusahaan. Bisa diingat kembali juga pada tahun 2015 kemarin, kondisi perekonomian Indonesia yang masih rentan menyebabkan lemahnya kurs rupiah terhadap dollar Amerika Serikat (US \$). Nilai rupiah saat itu terhadap US \$ melebihi Rp 14.200 dimana merupakan nilai terlemah selama 17 tahun terakhir setelah krisis moneter. Hal ini tentu saja mengkhawatirkan karena perusahaan-perusahaan di Indonesia melakukan peminjaman kepada investor asing terutama Amerika Serikat dan dikhawatirkan tidak mampu untuk melunasi hutang-hutangnya dan mulai mengalami Financial Distress. Dampak kenaikan dollar ini mempengaruhi perusahaan-perusahaan yang ada di Indonesia karena beberapa perusahaan tidak mampu memenuhi kewajiban finansialnya (Debt Default) dan tidak mampu membiayai kegiatan operasinya. Perusahaan-perusahaan tersebut akhirnya melakukan Pemutusan Hubungan Kerja (PHK) kepada karyawanya dikarenakan kerugian tersebut (www.kompasiana.com)

Ketidakmampuan memenuhi kewajiban finansial oleh suatu perusahaan mengindikasikan bahwa perusahaan tersebut telah mengalami permasalahan keuangan yang dapat memicu ke kondisi financial distress. Ketidakmampuan suatu perusahaan sebenarnya dapat diketahui dari informasi perusahaan yang berasal dari laporan keuangannya. Sebagai contoh, PT Toshiba pada tahun 2017 ini mengalami debt default. PT Toshiba mengonfirmasi pernyataan tersebut dengan memberikan laporan keuangannya dimana beban perusahaan telah lebih tinggi dibandingkan asset yang dimiliki perusahaan.Hal ini sebenarnya sudah dapat diperkirakan karena berdasarkan laporan keuangan PT Toshiba pada akhir tahun 2016 telah mengindikasikan kerugian sebesar 995 milliar yen. Selain PT Toshiba, perusahaanperusahaan lain bahkan telah menutup usahaanya pada tahun 2016. Salah satu perusahaan yang tercatat menutup usahanya pada tahun 2016 adalah Ford. Kerugian selama beberapa tahun terakhir merupakan faktor utama hengkangnya Ford dari Indonesia. Permasalahan keuangan yang terjadi ini menjelaskan bahwa laporan keuangan suatu perusahaan merupakan suatu hal penting yang dapat menjelaskan kondisi suatu perusahaan. (www.Kompas.com)

Berdasarkan uraian diatas maka peneliti tertarik untuk melakukan penelitian berjudul "Analisis Pengaruh Arus Kas Operasi, Likuiditas, Leverage, Diversifikasi, dan Ukuran Perusahaan Terhadap Financial Distress Pada Perusahaan-Perusahaan Manufaktur Sektor Aneka Industri Yang Terdaftar Di Bursa Efek Indonesia (BEI) 2014-2016.”

\section{Tinjauan Pustaka}

\section{Teori Agensi}

Jensen dan Meckling
menjelaskan hubungan keagenan terjadi
dimana terdapat satu atau lebih orang
(prinsipal) memberikan perintah kepada orang
lain (agen) untuk melakukan jasa atas nama
prinsipal dan memberikan juga kuasa kepada


agen untuk membuat keputusan yang dianggap baik untuk prinsipal. Pemberian kekuasaan ini juga mengartikan bahwa terjadinya kontrak antara prinsipal dan agen. Kuasa yang diterima oleh agen ini nantinya akan digunakan agen dalam mengelolah perusahaan agar semakin baik sesuai dengan keinginan prinsipal. Agen yang lebih mengetahui informasi yang lebih baik mengenai perusahaan memungkinkan untuk melakukan tindakan yang tidak sesuai keinginan prinsipal untuk kepentingan perusahaan melainkan kepentingan sendiri

\section{Teori Resource Based View}

Barney (2008) ini menjelaskan bahwa RBV merupakan sebuah model kinerja suatu perusahaan yang berfokus dengan sumber dayanya (Resources) dan kemampuan (Capabilities) suatu perusahaan mengendalikan sumber dayannya dalam rangka mencapai keunggulan bersaing. Sumber daya yang dimaksudkan adalah aset berwujud dan aset tidak berwujud yang perusahaan dapat kendalikan untuk digunakan dalam implementasi strategi sedangkan kemampuan yang dimaksudkan adalah bagian dari sumber daya perusahaan baik itu aset berwujud dan aset tidak berwujud yang dapat membuat perusahaan unggul dibandingkan sumber daya yang lain.

\section{Teori Efek Coinsurance}

Su (2010) menjelaskan efek coinsurance sebagai dampak dari strategi diversifikasi yang memungkinkan perusahaan dengan arus kas yang tidak sempurna dapat mengurangi masalah pendapatan, dimana perusahaan yang melakukan diversifikasi juga dapat melakukan penghematan pajak karena kerugian yang dibeberapa segmen ditutupi oleh segmen yang mengalami keuntungan. Pendekatan coinsurance effect ini mengacu pada upaya mengurangi risiko operasional yang terjadi ketika sebuah perusahaan melakukan beberapa usaha, dimana arus kas masing-masing bisnis tidak berkorelasi satu sama lain (Fathan, 2014).

\section{Teori Akuntansi Positif (PAT)}

Watts dan Zimmerman menjelaskan teori akuntansi positif sebagai alasan dasar penentuan standar akuntansi yang dilakukan manajemen dimana sebagai untuk keuntungannya sendiri. Pada intinya teori akuntansi positif berupaya untuk menjelaskan dengan lebih baik mengenai proses penetapan standar akuntansi pada suatu perusahaan dan dampak pada perusahaan dengan penetapan standar akuntansi tersebut.

\section{Financial Distress}

Financial disstres adalah kondisi yang menggambarkan keadaaan sebuah perusahaan yang sedang mengalami kesulitan keuangan, artinya perusahaan berada dalam posisi yang tidak aman dari ancaman kebrangkutan atau kegagalan pada usaha perusahaaan tersebut.Platt dan Platt (2002) mendefinisikan financial distress sebagai tahap penurunan kondisi keuangan yang terjadi sebelum terjadinya kebangkrutan ataupun likuidasi. Menurut Brigham dan Gapenski (1994) ada beberapa defisini kesulitan keuangan sesuai tipenya, yaitu :

\section{(1)Economic failure}

Economic failure atau kegagalan ekonomi adalah keadaan dimana pendapatan perusahaan tidak dapat menutupi total biaya, termasuk cost of capitalnya. Bisnis ini dapat melanjutkan operasinya sepanjang kreditur mau menyediakan modal dan pemiliknya mau menerima tingkat pengembalian (rate of return) di bawah pasar. Meskipun tidak ada suntikan modal baru saat aset tua sudah harus diganti, perusahaan dapat juga menjadi sehat secara ekonomi. 
(2)Business failure

Kegagalan bisnis didefinisikan sebagai bisnis yang menghentikan operasi dengan akibat kerugian kepada kreditur.

(3)Technical insolvency

Sebuah perusahaan dikatakan dalam keadaan technical insolvency jika tidak dapat memenuhi kewajiban lancar ketika jatuh tempo. Ketidakmampuan membayar hutang secara teknis menunjukkan kekurangan likuiditas yang sifatnya sementara, yang jika diberi waktu, perusahaan mungkin dapat membayar hutangnya dan survive. Di sisi lain, jika technical insolvency adalah gejala awal kegagalan ekonomi, ini mungkin menjadi perhentian pertama menuju bencana keuangan (financial disaster).

(4)Insolvency in bankruptcy

Sebuah perusahaan dikatakan dalam keadaan Insolvent in bankruptcy jika nilai buku hutang melebihi nilai pasar aset. Kondisi ini lebih serius daripada technical insolvency karena, umumnya, ini adalah tanda economic failure, dan bahkan mengarah kepada likuidasi bisnis. Perusahaan yang dalam keadaan insolvent in bankruptcy tidak perlu terlibat dalam tuntutan kebangkrutan secara hukum

(5)Legal bankruptcy

Perusahaan dikatakan bangkrut secara hukum jika telah diajukan tuntutan secara resmi dengan undangundang.

\section{Arus Kas Operasi}

Aktivitas operasi adalah aktivitas penghasil utama pendapatan perusahaan. Arus kas operasi menentukan apakah operasi akan menghasilkan kas untuk melunasi pinjaman dan memelihara kemampuan operasi perusahaan , membayar dividen dan melakukan investasi. Menurut Keiso (2011), arus kas operasi merupakan kategori yang paling penting karena memberikan gambaran uang kas dari operasi perusahaan

\section{Likuiditas}

Gitman dan Zutter (2015) menjelaskan likuiditas sebagai pengukur kemampuan untuk memenuhi kewajiban jangka pendeknya yang jatuh tempo. Likuiditas juga lebih mengarah kepada neraca suatu perusahaan yang dimana memberikan informasi perusahaan mengenai kemudahan dalam membayar hutangnya. Wahyu (2009) juga menjelaskan hal yang sama, rasio likuiditas ini menunjukan aktiva lancar perusahaan yang paling likuid dan dapat segera digunakan untuk memenuhi kewajiban jangka pendeknya. Perusahaan yang semakin likuid mengartikan bahwa perusahaan dapat menjamin pengembalian hutang jangka pendek atau jangka panjang yang akan jatuh tempo maupun sudah jatuh tempo.

\section{Leverage}

Leverage merupakan rasio yang menunjukan bagaimana suatu perusahaan bergantung pada hutang dalam pembiayaaan melakukan kegiatan operasionalnya. Gitman dan Zuter (2015) menjelaskan financial leverage sebagai pembesaran resiko dan pengembalian, seperti hutang dan saham preferen untuk penggunaan fixed cost financing. Rasio leverage ini nantinya akan menjelaskan aktifitas penggunaan dana perusahaan yang berasal dari pihak ketiga dalam bentuk hutang untuk membiayai kegiatan perusahaan (Putri dan Merkusiwati, 2014).

\section{Diversifikasi}

Diversifikasi merupakan salah satu strategi yang biasanya perusahaan gunakan 
untuk mempertahankan eksistensinya. Persaingan yang ketat dalam ekonomi global, membuat perusahaan harus selalu mempunyai strategi dalam mencari laba. Menurut Harto (2005) diversifikasi merupakan bentuk pengembangan usaha dengan cara memperluas jumlah segmen bisnis, geografis maupun memperluas market share yang ada atau dengan mengembangkan berbagai jenis produk yang dimiliki. Diversifikasi yang dilakukan perusahaan nantinya dapat berkaitan ataupun tidak berkaitan dengan usaha inti yang dijalankan perusahaan. Dalam penelitian ini, diversifikasi suatu perusahaan merupakan banyaknya jenis produk-produk yang dihasilkan perusahaan yang dilaporan pada segmen usaha perusahaan.

\section{Ukuran Perusahaan (Size)}

Ukuran perusahaan menjelaskan besar kecilnya suatu perusahaan. Adindha (2017) juga menjelaskan ukuran perusahaan menggambarkan besarnya total aset yang dimiliki perusahaan. Perusahaan yang besar tentunya memiliki aset yang lebih banyak dibandingkan perusahaan kecil dalam memaksimalkan laba yang akan diperolehnya. Proksi untuk mengukur ukuran perusahaan dapat menggunakan jumlah karyawan, total aset, jumlah penjualan, dan kapitalisasi pasar. Namun dalam menggunakan nilai-nilai seperti total aset dan jumlah penjualan, variabel akan sangat besar yang bisa mencapai milliar ataupun triliun. Untuk itu, nilai yang terlalu besar dapat disederhanakan dengan mentransformasikannya ke dalam logaritma natural.

\section{Hipotesis}

$\mathrm{H}_{1}$ : Arus Kas Operasi berpengaruh negatif terhadap financial distress suatu perusahaan

$\mathrm{H}_{2}$ : Rasio likuiditas berpengaruh negatif terhadap financial distress suatu perusahaan
$\mathrm{H}_{3}$ : Rasio leverage berpengaruh positif terhadap financial distress suatu perusahaan

$\mathrm{H}_{4}$ : Diversifikasi berpengaruh negatif terhadap financial distress suatu perusahaan

$\mathrm{H}_{5}$ : Ukuran perusahaan berpengaruh negatif terhadap financial distress suatu perusahaan

\section{Metode Penelitian}

\section{Objek Penelitian}

Objek penelitian ini adalah laporan keuangan tahunan perusahaan manufaktur sektor aneka industri yang terdaftar dalam Bursa Efek Indonesia periode 2014-2016 yang telah di audit. Laporan keuangan ini akan digunakan untuk memperoleh data berupa arus kas operasi yang diukur dengan membagi dengan total kewajiban, likuiditas yang diukur dengan current ratio, Leverage yang diukur dengan DAR, diversifikasi yang diukur dengan indeks herfindhal, dan ukuran perusahaan yang diukur dengan log total aset. Data yang di observasi ini berupa data sekunder yang di download terlebih dahulu dari website Indonesia Capital Market Directory (ICMD) yaitu www.idx.co.id .

\section{Variabel Penelitian}

\section{(1)Variabel Dependen}

Financial distress merupakan variabel dependen dan variabel dummy dalam penelitian ini. Pengukuran perusahaan yang mengalami financial distress berdasarkan laba bersih negatif perusahaan selama dua tahun berturutturut (Luciana dan Kristijadi, 2003). Perusahaan yang mengalami laba bersih negatif dua tahun berturut-turut akan dikategorikan 1 dan untuk perusahaan yang tidak mengalami laba bersih negatif dua tahun berturut-turut akan dikategorikan 0 . 


\section{(2)Variabel Independen}

\section{(a)Arus Kas Operasi}

Dalam penelitian ini, arus kas operasi akan diukur melalui rasio dengan rumus arus kas operasi dibagi dengan total kewajiban. Membandingkan antara arus kas operasi dengan total kewajiban ini akan memberikan gambaran mengenai kemampuan pembayaran hutang atas perusahaan kedepannya. Rasio arus kas operasi perusahaan yang semakin besar nantinya akan menunjukan juga bahwa perusahaan tidak gagal dalam menjalankan bisnisnya. Rumus pengukuran arus kas operasi dapat dilihat sebagai berikut :

$$
C F O=\frac{\text { Arus Kas Operasi }}{\text { Total Kewajiban }}
$$

\section{(b)Likuiditas}

Proksi likuiditas yang akan digunakan dalam penelitian ini adalah current ratio. Perusahaan yang likuid akan memiliki current ratio diatas satu. Namun, current ratio yang terlalu tinggi juga tidak baik bagi perusahaan karena menunjukan adanya pengelolaan uang kas yang buruk karena banyaknya uang kas yang menganggur. Rumus current ratio berdasarkan Gitman dan Zutter (2015) dapat dilihat dibawah ini :

$$
C R=\frac{\text { CurrentAsset }}{\text { CurrentLiabilities }}
$$

\section{(c)Leverage}

Leverage dalam penelitian ini akan diukur menggunakan DAR. Rasio DAR merupakan rasio yang digunakan untuk mengukur perbandingan antara total hutang dengan total aset perusahaan. Apabila rasio

\section{Teknik Pengambilan Sampel}

DAR tinggi, artinya pendanaan perusahaan oleh hutang banyak dan mempunyai kewajiban membayar bunga pinjaman yang banyak juga. Rumus DAR berdasarkan Gitman dan Zutter (2015) dapat dilihat pada dibawah ini :

$$
D A R=\frac{\text { Total Liabilities }}{\text { Total Aset }}
$$

\section{(d)Diversifikasi}

Diversifikasi dalam penelitian ini akan diukur menggunakan indeks herfindhal. Perusahaan dalam menjalankan bisnisnya ada yang bersegmen tunggal ataupun multi segmen. Pengukuran indeks herfindhal ini dapat digunakan untuk melihat banyaknya segmen usaha yang dijalankan perusahaan. Rumus indeks herfindhal dapat dilihat dibawah ini :

$$
\begin{aligned}
& \mathbf{H}=\sum_{i=1}^{n} \text { segsales }^{2} \\
& /\left(\sum_{i=1}^{n} \text { sales }\right)^{2}
\end{aligned}
$$

\section{(e)Ukuran Perusahaan (Size)}

Ukuran perusahaan dalam penelitian ini akan diukur menggunakan $\log$ total aset. Penggunaan log ini bertujuan untuk mendapatkan nilai yang tidak terlalu besar dari total aset perusahaan. Perusahaan yang memiliki total aset yang besar menunjukan semakin besar ukuran perusahaan juga. Rumus ukuran perusahaan dapat dilihat dibawah ini :

$$
\text { Size }=\operatorname{Ln}(\text { Total asset })
$$

Pengambilan sampel dilakukan dengan nonprobabilistic sampling metode purposive 
sampling dengan adanya kriteria yang ditentukan agar memperoleh sampel yang sesuai. Berikut ini kriteria-kriteria yang ditetapkan antara lain :

\begin{tabular}{|l|l|}
\hline \multicolumn{1}{|c|}{ Kriteria } & Jumlah \\
\hline Perusahaan manufaktur sektor aneka industri yang terdaftar di BEI berdasarkan & 41 \\
\hline Perusahaan yang baru terdaftar selama periode penelitian (2014-2016) & $(2)$ \\
\hline Perusahaan yang melaporkan dengan mata uang selain rupiah & $(15)$ \\
\hline Perusahaan yang tidak memiliki informasi segmen yang lengkap & $(1)$ \\
\hline Total Sampel terpilih & $\mathbf{2 2}$ \\
\hline Total data yang dipakai (22*3tahun) & 66 \\
\hline
\end{tabular}

Sampel penelitian berjumlah 22 perusahaan dengan 3 tahun sehingga total sampel yang digunakan adalah 66 data perusahaan. Menurut Malhotra (1993), ukuran sampel minimal adalah 4 atau 5 kali jumlah

\section{Teknik Analisis Data}

\section{(1)Deskripsi Statistik}

Statistik deskriptif memberikan gambaran atau deskripsi suatu data yang dilihat dari nilai rata-rata (mean), standar deviasi, varian, maksimum, minimum, sum, range, kurtosis dan skewness (kemencengan distribusi) (Ghozali , 2016).

\section{(2)Uji Kesamaan Koefisien (Uji Pooling)}

Penelitian ini menggunakan data time series sehingga perlu dilakukan suatu pengujian untuk mengetahui apakah pooling data penelitian (penggabungan data cross-sectional dengan time series) dapat dilakukan. Pengujian ini nantinya untuk mengetahui apakah ada perbedaan koefisien antara regresi yang ada.

\section{(3)Uji Regresi Logistik}

Teknik analisis regresi yang digunakan dalam penelitian ini adalah analisis regresi logistik biner (binary logistic regression) yang variabel dependennya berupa variabel kategorik (dikotomi/biner). Model Binary Logistic Regression dalam penelitian ini dapat dinyatakan sebagai berikut : variabel yang diteliti. Variabel dalam penelitian ini adalah 5 sehingga sampel minimal $20(4 \mathrm{x}$ 5) telah terpenuhi.

$$
\operatorname{Ln} \frac{P}{(1-P)}=\beta_{0}+\beta_{1} \mathrm{CFFO}+
$$

$\beta_{2} \mathrm{LIK}+\beta_{3} \mathrm{LEV}+\beta_{4} \mathrm{DIV}+$

$\beta_{5}$ SIZE $+\varepsilon \ldots$.

Pengujian regresi logistik terdiri dari beberapa pengujian. Berikut ini adalah pengujian-pengujian regresi logistik yang akan diuji dalam penelitian ini :

(a)Uji Kelayakan Model Regresi

(Uji Hosmer and Lemeshow's Goodness)

Hosmer and Lemeshow's Goodness of Fit Test digunakan untuk menguji hipotesis nol bahwa data empiris cocok atau sesuai dengan model (tidak ada perbedaan antara model dengan data sehingga model dapat dikatakan fit) (Ghozali , 2016). Jika nilai Hosmer and Lemeshow's Goodness of Fit Test $\leq 0,05$, maka hipotesis nol ditolak yang berarti ada perbedaan signifikan antara model dengan nilai observasinya, namun jika nilai Hosmer and Lemeshow's Goodness of Fit Test > 0,05, maka hipotesis nol tidak dapat ditolak yang berarti model mampu 
memprediksi nilai observasinya atau dapat dikatakan model dapat diterima karena cocok dengan data observasinya (Ghozali , 2016).

\section{(b)Uji Hipotesis (Uji Wald)}

Pengujian hipotesis dilakukan untuk mengetahui apakah variabel independen secara individual berpengaruh terhadap variabel dependen. Uji wald disini dapat digunakan untuk mengetahui secara parsial apakah variabel independen mempengaruhi variabel dependennya. Kriteria Pengambilan keputusan adalah jika nilai $(\mathrm{sig} / 2)<$ tingkat signifikansi yang ditetapkan $(\alpha=$ $5 \%)$, maka tolak Ho. Jika nilai (sig/2) $\geq$ tingkat signifikansi yang ditetapkan $(\alpha=5 \%)$, maka tidak tolak Ho.

(c)Uji Penilaian Keseluruhan Model (Overall model fit)

Statistik -2LogL dapat digunakan untuk melakukan pengujian penilaian keseluruhan model. Apabila nantinya terdapat penurunan nilai statistik -2LogL pada model awal dibandingkan dengan nilai statistik -2LogL pada model final, dapat dikatakan bahwa variabel independennya secara bersama-sama (stimulan) mempengaruhi variabel dependennya.

(d)Nagelkerke's R Square

Nagelkerke's $R \quad$ Square merupakan modifikasi dari koefisien Cox dan Snell dimana Cox dan Snell merupakan ukuran yang mencoba meniru ukuran $\mathrm{R}^{2}$ pada multiple regression yang didasarkan pada teknik estimasi likelihood dengn nilai maksimum kurang dari 1 (satu) sehingga sulit diinterpretasikan. Nilai Nagelkerke's $R \quad$ Square menjelaskan seberapa jauh variable independen dapat menjelaskan variabel dependen dalam model penelitian.

\section{Hasil dan Pembahasan}

a. Analisis Deskriptif

\begin{tabular}{|l|l|r|r|r|r|}
\hline & $\mathrm{N}$ & \multicolumn{1}{|c|}{ Minimum } & \multicolumn{1}{c|}{ Maximum } & \multicolumn{1}{c|}{ Mean } & Std. Deviation \\
\hline CFFO & 66 &,- 41 &, 86 &, 1162 &, 21599 \\
\hline LIK & 66 &, 35 & 3,41 & 1,4986 &, 70949 \\
\hline LEV & 66 &, 17 & 1,57 &, 5562 &, 24782 \\
\hline DIV & 66 &, 22 & 1,00 &, 7036 &, 25702 \\
\hline SIZE & 66 & 25,95 & 33,20 & 28,3568 & 1,56416 \\
\hline FD & 66 &, 00 & 1,00 &, 1515 &, 36130 \\
\hline $\begin{array}{l}\text { Valid N } \\
\text { (listwise) }\end{array}$ & 66 & & & & \\
\hline
\end{tabular}

Hasil analisis dengan menggunakan statistik deskriptif dapat diketahui bahwa

(1)Nilai rata-rata arus kas operasi (CFFO) sebesar 0,1162 menunjukan bahwa rata-rata perusahaan yang diteliti memiliki arus kas yang positif. Nilai tertinggi arus kas operasi sebesar 0,86 adalah SMSM pada tahun 2016 dan nilai terendah arus kas operasi sebesar -0,41 adalah LPIN pada tahun 2014 , sedangkan nilai 
standard deviation arus kas operasi sebesar 0,21599 menunjukan bahwa data tersebar mendekati nilai ratarata.

(2)Nilai rata-rata likuiditas (LIK) sebesar 1,4986 menunjukan bahwa rata-rata perusahaan yang diteliti merupakan perusahaan yang likuid. Nilai tertinggi likuiditas sebesar 3,41 adalah KBLI pada tahun 2016 dan nilai terendah likuiditas sebesar 0,35 adalah MYTX pada tahun 2015 , sedangkan nilai standard deviation likuiditas sebesar 0,70949 menunjukan bahwa data tersebar mendekati nilai rata-rata.

(3)Nilai rata-rata leverage (LEV) sebesar 0,5562 menunjukan bahwa rata-rata perusahaan yang diteliti memiliki struktur modal yang baik dengan total hutang yang dibawah total asetnya. Nilai tertinggi leverage sebesar 1,57 adalah MYTX pada tahun 2016 dan nilai terendah leverage sebesar 0,17 adalah INDS pada tahun 2016,

b. Uji Kesamaan Koefisien (Uji Pooling)

Hasil Uji Kesamaan Koefisien dapat dilihat bahwa nilai signifikansi untuk Dt1CFFO, Dt1LIK , Dt1LEV , Dt1DIV, Dt1SIZE ,Dt2CFFO, Dt2LIK, Dt2LEV, Dt2DIV, dan Dt2SIZE memiliki nilai signifikansi lebih besar dari 0,05. Hasil ini menunjukan bahwa data dalam penelitian telah lolos uji kesamaan koefisien sehingga data yang diuji dapat digabung atau dipool. sedangkan nilai standard deviation leverage sebesar $\quad 0,24782$ menunjukan bahwa data tersebar mendekati nilai rata-rata.

(4)Nilai rata-rata diversifikasi (DIV) sebesar 0,7036 menunjukan bahwa rata-rata perusahaan yang diteliti merupakan perusahaan yang masih terkonsentrasi segmennya. Perusahaan yang paling diversifikasi sebesar 0,22 adalah KRAH pada tahun 2015,sedangkan nilai standard deviation diversifikasi sebesar 0,25702 menunjukan bahwa data tersebar mendekati nilai rata-rata.

(5)Nilai rata-rata ukuran perusahaan (SIZE) adalah sebesar 28,3568. Nilai tertinggi size sebesar 33,20 adalah ASII pada tahun 2016 dan nilai terendah sebesar 25,95 adalah LPIN pada tahun 2014 sedangkan nilai standard deviation size sebesar 1,56416 menunjukan bahwa data tersebar tidak mendekati nilai ratarata.

\begin{tabular}{|c|l|}
\hline Model & Sig \\
\hline Dt1CFFO & 0,615 \\
\hline Dt1LIK & 0,979 \\
\hline Dt1LEV & 0,825 \\
\hline Dt1DIV & 0,332 \\
\hline Dt1SIZE & 0,657 \\
\hline Dt2CFFO & 0,617 \\
\hline Dt2LIK & 0,9 \\
\hline Dt2LEV & 0,982 \\
\hline Dt2DIV & 0,344 \\
\hline Dt2SIZE & 0,914 \\
\hline
\end{tabular}

c. Uji Kelayakan Model Regresi (Uji Hosmer and Lemeshow's Goodness)

\begin{tabular}{|c|c|c|c|}
\hline Step & Chi-square & Df & Sig \\
\hline 1 & 4,587 & 7 & ,710 \\
\hline
\end{tabular}

Goodness of Fit Test yang diukur dengan hosmer and Lemeshow's Test diperoleh nilai signifikasi sebesar 0,710 dimana lebih besar dari tingkat signifikansi 0,05 . Hasil ini mengartikan bahwa Ho tidak dapat ditolak sehingga dapat dikatakan bahwa data empiris cocok atau sesuai dengan model yang dihipotesiskan karena tidak ada perbedaan antara model dengan data.
Dari hasil Uji Wald diketahui bahwa signifikansi dari variabel CFFO sebesar $(0,758 / 2) 0,379>\alpha(0,05)$, sehingga tidak tolak Ho yang berarti arus kas operasi tidak terbukti berpengaruh signifikan terhadap financial distress. Signifikansi dari variabel LIK sebesar $(0,138 / 2) 0,069>\alpha(0,05)$, sehingga tidak tolak Ho yang berarti likuiditas 
tidak terbukti berpengaruh signifikan terhadap financial distress.

d. Uji Hipotesis (Uji Wald) dan Model Regresi

\begin{tabular}{|l|r|r|r|r|r|}
\hline & \multicolumn{1}{|c|}{ B } & \multicolumn{1}{c|}{ S.E. } & \multicolumn{1}{c|}{ Wald } & \multicolumn{1}{c|}{ df } & \multicolumn{1}{c|}{ Sig } \\
\hline CFFO & 1,712 & 5,558 &, 095 & 1 &, 758 \\
\hline LIK & $-2,840$ & 1,913 & 2,203 & 1 &, 138 \\
\hline LEV & 9,025 & 4,695 & 3,695 & 1 &, 055 \\
\hline DIV &, 063 & 2,309 &, 001 & 1 &, 978 \\
\hline SIZE &,- 056 &, 347 &, 027 & 1 &, 871 \\
\hline CONSTANT & $-3,031$ & 9,750 &, 097 & 1 &, 756 \\
\hline
\end{tabular}

Persamaan model regresi logistik setelah mengolah data dinyatakan sebagai berikut :

$$
\operatorname{Ln} \frac{\mathrm{P}}{(1-\mathrm{P})}=-3,031+1,712 \mathrm{CFFO}-2,840 \mathrm{LIK}+9,025 \mathrm{LEV}+0,063 \text { DIV-0,56 SIZE }
$$

Signifikansi dari variabel LEV sebesar $(0,055 / 2) 0,0275<\alpha(0,05)$, sehingga tolak Ho yang berarti Leverage berpengaruh signifikan terhadap financial distress. Signifikansi dari variabel DIV sebesar $(0,978 / 2) 0,489>\alpha$ $(0,05)$, sehingga tidak tolak Ho yang berarti diversifikasi tidak terbukti berpengaruh signifikan terhadap financial distress. Signifikansi dari variabel SIZE sebesar $(0,871 / 2)$ 0,4355> $\alpha(0,05)$, sehingga tidak tolak Ho yang berarti ukuran perusahaan tidak terbukti berpengaruh signifikan terhadap financial distress.

e. Uji Penilaian Keseluruhan Model (Overall model fit)

\begin{tabular}{|l|l|}
\hline Keterangan & -2 Log Likehood \\
\hline Block Number $=0$ & 57,133 \\
\hline Block Number $=1$ & \\
\hline
\end{tabular}

Dapat dilihat bahwa terjadi penurunan pada nilai -2 Log Likelihood pada block number $=1$ dibandingkan dengan nilai -2 Log Likelihood pada block number $=0$ dari yang bernilai 57,133 menjadi 28,962. Penurunan nilai regresi ini menunjukan bahwa model regresi menjadi lebih baik dan dapat disimpulkan bahwa regresi kedua setelah memasukan variabel-variabel independen CFFO, LIK, LEV, DIV, dan SIZE membuat prediksi menjadi lebih baik.

\section{f. Nagelkerke's R Square}

\begin{tabular}{|l|r|r|r|}
\hline Step & -2 Log Likehood & Cox \& Snell R Square & Nagelkerke R Square \\
\hline 1 & 28,962 &, 338 &, 589 \\
\hline
\end{tabular}

Dapat dilihat nilai Nagelkerke's $R$ Square sebesar 0,589 yang mengartikan bahwa variabel dependen (financial distress) dipengaruhi sebesar 58,9 \% oleh variabel independennya (Arus Kas Operasi , Likuiditas, Leverage, Diversifikasi, dan Ukuran perusahaan). Untuk sisanya sebesar $41,1 \%$, 
dipengaruhi oleh variabel-variabel lain yang tidak diteliti dalam penelitian ini.

\section{Pembahasan}

\section{(1)Pengaruh Arus Kas Operasi terhadap Financial Distress}

Dari tabel hasil pengujian Wald dapat dilihat bahwa nilai signifikansi dari variabel CFFO adalah sebesar $(0,758 / 2) 0,379>\alpha(0,05)$. Hasil ini mengartikan bahwa arus kas operasi tidak berpengaruh secara signifikan terhadap kondisi financial distress suatu perusahaan. Hal seperti ini dapat disebabkan oleh aktivitas arus kas perusahaan lainnya. Perusahaan yang memiliki arus kas operasi yang positif namun memiliki arus kas investasi dan pendanaan yang negatif dapat menyebabkan total arus kas perusahaan menjadi negatif. Arus kas perusahaan yang negatif ini pada akhirnya menyebabkan kesulitan keuangan bagi perusahaan karena perusahaan tidak memiliki dana untuk membiayai kegiatan operasional perusahaan sehari-harinya.

\section{(2)Pengaruh Likuiditas terhadap Financial Distress}

Dari tabel hasil pengujian Wald dapat dilihat bahwa nilai signifikansi dari variabel LIK adalah sebesar $(0,138 / 2) 0,069>\alpha(0,05)$. Hasil ini mengartikan bahwa likuiditas tidak berpengaruh secara signifikan terhadap financial distress suatu perusahaan. Hal ini dapat disebabkan uang kas yang dimiliki perusahaan sekarang ini sebenarnya merupakan pinjaman baru yang dilakukan perusahaan. Tidak tersedianya uang untuk melunasi hutang-hutang yang telah jatuh tempo memaksa perusahaan untuk melakukan peminjaman baru untuk segera melunasi hutang jatuh tempo tersebut. Peminjaman baru tersebut tentunya menimbulkan biaya baru bagi perusahaan sehingga dapat menyebabkan kesulitan keuangan. Selain itu, pada tabel deskriptif juga menunjukan bahwa rata-rata perusahaan yang diteliti adalah perusahaan yang likuid sehingga menjelaskan mengapa likuiditas tidak berpengaruh secara signifikan terhadap financial distress dalam penelitian ini.

\section{(3)Pengaruh Leverage terhadap Financial Distress}

Dari tabel hasil pengujian Wald dapat dilihat bahwa nilai signifikansi dari variabel LEV adalah sebesar $(0,055 / 2) 0,0275<\alpha(0,05)$ dan nilai B sebesar 33,057. Hasil ini mengartikan bahwa ada cukup bukti Leverage berpengaruh secara signifikan dengan arah positif terhadap financial distress suatu perusahaan. Hutang yang tinggi dimiliki suatu perusahaan tentunya mewajibkan perusahaan untuk membayar bunga yang tinggi juga. Perusahaan yang memiliki hutang semakin tinggi jika tidak diikuti dengan hasil penjualan yang tinggi dan stabil dapat memungkinkan terjadinya gagal bayar yang dapat menyebabkan kesulitan keuangan bagi perusahaan.

\section{(4)Pengaruh Diversifikasi terhadap Financial Distress}

Dari tabel hasil pengujian Wald dapat dilihat bahwa nilai signifikansi dari variabel DIV adalah sebesar $(0,978 / 2) 0,489>\alpha(0,05)$. Hasil ini mengartikan bahwa diversifikasi tidak berpengaruh secara signifikan 
terhadap financial distress suatu perusahaan. Teori efek coinsurance yang mengatakan strategi diversifikasi mampu menurunkan kemungkinan terjadinya financial distress tidak terbukti dalam penelitian ini. Hal ini dapat disebabkan karena strategi diversifikasi yang dijalankan perusahaan tidak tepat sasaran sehingga tidak mampu untuk menurunkan kemungkinan terjadinya financial distress.

\section{(5)Pengaruh Ukuran Perusahaan terhadap Financial Distress}

Dari tabel hasil pengujian Wald dapat dilihat bahwa nilai signifikansi dari variabel SIZE adalah sebesar $(0,871 / 2) 0,4355>\alpha(0,05)$. Hasil ini mengartikan bahwa ukuran perusahaan tidak berpengaruh secara signifikan terhadap financial distress suatu perusahaan. Dalam teori RBV telah dijelaskan bahwa tidak hanya dengan sumber daya yang dimiliki perusahaan dalam rangka mencapai perusahaan yang unggul bersaing, kemampuan mengolah sumber daya juga merupakan hal penting di dalam perusahaan. Sumber daya yang besar tapi tanpa adanya pengolahan yang baik dapat menjadikan sumber daya tersebut menjadi percuma.

\section{Kesimpulan dan Saran}

\section{Kesimpulan}

Hasil penelitian menunjukan bahwa tidak terdapat cukup bukti bahwa arus kas operasi, likuiditas, diversifikasi dan ukuran perusahaan berpengaruh secara signifikan terhadap financial distress suatu perusahaan. Sedangkan leverage terdapat cukup bukti bahwa berpengaruh secara signifikan dengam arah positif terhadap kemungkinan financial distress suatu perusahaan

\section{Saran}

Mengingat banyaknya keterbatasan dari penelitian ini, maka untuk itu peneliti akan memberikan saran yang dapat digunakan dalam penelitian selanjutnya , antara lain :

1. Penggunaan pengukuran lain terhadap financial distress berupa Altman Z Score namun menggunakan variabel independenya yang bukan berupa rasio keuangan karena pengukuran Altman $Z$ score menyerupai pengukurang rasio keuangan. Selain itu, dalam penggunaan pengukuran financial distress dengan laba bersih negatif dua tahun berturut-turut dianjurkan untuk dipertimbangkan terlebih dahulu karena memiliki beberapa keterbatasan.

2. Menetapkan kriteria sample yang lebih banyak sehingga penentuan suatu perusahaan yang mengalami financial distress dapat semakin baik. Contohnya dengan menambahkan kriteria perusahaan yang tidak membayarkan dividenya.

3. Menggunakan pengukuran lain terhadap variabel-variabel seperti arus kas, likuiditas, diversifikasi, dan ukuran perusahaan jika ingin memperoleh hasil yang signifikan

4. Pada penelitian ini, sebelumnya peneliti telah menggunakan variabel independen berupa profitabilitas yaitu ROA namun membuat hasil penelitian menjadi tidak relevan. Untuk itu, pengukuran profitabilitas dengan ROA lebih baik tidak digunakan.

5. Penambahan variabel-variabel lain untuk penelitian selanjutnya dapat menggunakan variabel seperti Good Corporate Goveranance, Firm Growth, dan sebagainya.

\section{Daftar Pustaka}

Adindha Sekar Ayu ,dkk. (2017), Pengaruh Likuiditas, Leverage, Profitabilitas, dan Ukuran Perusahaan Terhadap 
Financial Distress Pada Perusahaan Manufaktur Sektor Industri Dasar dan Kimia yang Terdaftar di Bursa Efek Indonesia Tahun 2012-2015, Jurnal Administrasi Bisnis Vol. 43 No.1 Februari 2017, pp 138-147.

Barney, Jay B. dan William S. Hesterly (2008), Strategic Management and Competitive Advantage, pp 94.

Brigham, Eugene F and Louis C. Gapenski (1994), Financial Management Theory and Practice, The Dryden Press, Seventh Edition.

Fathan, Ferdinand D. Saragih (2014), Pengaruh Corporate Diversification Terhadap Keputusan Struktur Modal Pada Perusahaan Non-Keuangan Yang Terdaftar Di Bursa Efek Indonesia Periode 2008-2012.

Ghozali, Imam (2016), Aplikasi Analisis Multivariate dengan Program IBM SPSS 23, Semarang; Badan penerbit Universitas Diponegoro.

Gitman, Lawrence dan Chad J. Zutter (2015), Principles of Managerial Finance, 14th edition, Global edition: Perason Education Limited.

Harto, Puji (2005), Kebijakan Diversifikasi Perusahaan dan Pengaruhnya Terhadap Kinerja Perusahaan: Studi Empiris Pada Perusahaan Publik Di Indonesia, Forum Penelitian, VIII.

Jensen, M. C and Meckling, W.H (1976), Theory of the Firm : Managerial Behavior, Agency Costs and Ownership Structure, Journal of Financial Economics, Oktober, 1976, V. 3, No. 4, pp. 305-360.

Keiso, Donald E., Jerry J. Weygandt \& Paul D. Kimmel (2011), Financial Acconting : IFRS Edition, Page 600601.
Luciana Spica Almilia dan Kristijadi (2003), Analisis Rasio Keuangan untuk Memprediksi Kondisi Financial Distress Perusahaan Manufaktur yang Terdaftar di BEJ, Jurnal dan Akuntansi Auditing Indonesia, vol. 7 No. 2.

Malhotra K. Naresh. 1993. Marketing Research An Applied Orientation, second edition, Prentice Hall International Inc, New Jersey

Platt, Harlan D. dan Marjorie B. Platt (2002), Predicting Corporate Financial Distress: Reflections on Choice-based Sample Bias, Journal of Economics and Finance, Illinois.

Putri , Ni Wayan Krisnayanti dan Merkusiwati , Ni Kt. Lely A. (2014), Pengaruh Mekanisme Corporate Goverance, Likuiditas, Leverage, dan Ukuran Perusahaan Pada financial distress, Jurnal akutansi Universitas Udayana 7.1 , pp. 93-106.

Su, Larry D. (2010), Ownership Structure Corporate Diversivication Strategies And Capital Structure in China's Publicy Listed Firm, Journal of Management Decision 2010, Vol 48 No.2,pp. 314-339.

Srikalimah , SE. ,MM (2017), Pengaruh Profitabilitas , Likuiditas dan Leverage dalam Memprediksi Financial Distress (Studi empiris pada Perusahaan Manufaktur yang Terdaftar di BEI Periode 2009-2013), Jurnal akuntansi dan ekonomi FE, Vol. 2 No. 1.

Wahyu Widarjo dan Doddy Setiawan (2009), Pengaruh Rasio Keuangan Terhadap Kondisi Financial Distress Perusahaan Otomotif, Jurnal Bisnis dan Akuntansi, pp. 107-119. 
Watts, Ross L. and Zimmerman, Jerold L. (1978), Towards a Positive theory Of The Determination of Accounting Standards,The Accounting Review, Vol LIII No. 1.

https://www.kompasiana.com/musniumar/1 0-dampak-negatif-pada-masyarakatmelemahnyarupiah_55f21cf34df9fd7e0e532e94

https://www.kompasiana.com/www.tekniki ndustri17.mercubuana.ac.id/manufac tur_55091577813311341cb1e389 http://ekonomi.kompas.com/read/2017/06/2 6/103000126/toshiba.alami.rugi.besa r.ini.sebabnya

http://otomotif.kompas.com/read/2016/01/2 5/181430415/Alasan.Ford.Gulung.Ti kar.di.Indonesia

https://www.sahamok.com/emiten/sektoraneka-industri/ 